\title{
Supporting BIICL
}

The need for BIICL's independent and impartial research, analysis and capacity building activities is greater than ever. We have ambitious plans to build on our successful track record of spreading knowledge and stimulating change through our research and related activities.

BIICL's ability to address emerging legal issues and respond to the most pressing global challenges depends on the ongoing support of our members, donors, funders and sponsors.

\section{BIICL 60+ Appeal}

Under the Chairmanship of Lord Neuberger of Abbotsbury, we have launched the BIICL 60+ Appeal to raise $£ 3$ million over the next five years. This will enable us to expand and develop our work on a wide range of legal issues affecting the world today, including those relating to international trade, climate change and technology.

Gifts to the BIICL 60+ Appeal are also helping to fund a major refurbishment of our office space. This renovation provides additional office accommodation for our growing team of researchers and a large attractive space for public events. Bringing our events and outreach, training and dissemination activities in-house will encourage the free-flow of ideas at the heart of the Institute and stimulate even greater collaboration between BIICL, the legal world and others interested in our work.

The 60+ Appeal Panel is comprised of the following members:

Lord Neuberger of Abbotsbury, Chair

Martin Paisner CBE, Vice Chair

Philip Bennett

Guy Beringer

Sir Franklin Berman KCMG QC

Sir William Blair

Lord Collins of Mapesbury

Professor Dr Malik Dahlan

Sir David Edward KCMG QC

Shaheed Fatima QC
James Furber

Sir Christopher Greenwood GBE CMG QC

Dame Rosalyn Higgins GBE QC

Lord Phillips of Worth Matravers KG

Nigel Pleming QC

Keith Ruddock

Harish Salve QC

Steve Williams

By supporting our Appeal, you will be helping BIICL address some of the most pressing global challenges, thus making a positive and lasting difference to our world.

We would be delighted to discuss your interest in supporting our work and welcome donations at all levels.

To find out more about the BIICL $60+$ Appeal, please contact

Diane Denny, Development Director:

$\mathrm{T}:+44(0) 2078625433$

E: d.denny@biicl.org

More information is also available at: www.biicl.org/60thappeal

You may wish to leave a legacy to BIICL in your will. In the UK the value of your gift will be deducted from your estate before inheritance tax is calculated.

US donors can donate through BIICL's affiliate, The International Rule of Law Project Inc. which is a 501 (c) (3) public charity (www.irolp.org). 


\section{BIICL ACTIVITIES}

\section{Research}

BIICL conducts research around the world across the broad range of public international law, private international law, comparative law and the rule of law. This includes areas such as competition law, European law, human rights law, international investment law, and product liability law. Our research often crosses traditional boundaries of law, so as to integrate private and public international law, and engages with national, European and comparative law.

Our research is primarily applied research, based on strong knowledge foundations. This enables our research to have practical consequences, establish influential recommendations for decisionmakers, and have an impact on law and policy around the world.

\section{Events}

BIICL organises an exciting and diverse programme of events throughout the year. These bring together leading speakers and participants from law firms, barristers' chambers, corporations, government, nongovernmental organisations, regulatory bodies, international organisations, academia, students and many others.

Our events deal with the many important contemporary international legal issues and developments. They include evening seminars and fullday conferences, open debates and confidential discussions. Events are generally open to all members and the public, and most events are CPD accredited for practitioners.

\section{Fora}

The Institute enhances its research activities through four specialist forums: The Investment Treaty Forum,
The Competition Law Forum, The Product Liability Forum and The Human Rights Due Diligence Forum.

These invitation only discussion and working groups bring together senior experts to share experiences and exchange opinions, contribute to policy initiatives, and promote research in these important areas of law and practice.

\section{Training and Development}

The provision of specific and general training on international and comparative legal matters is another of our important activities. These range from short courses on specific topics within the UK, to capacity building in developing states. We offer high level expertise and practical experience, including from our network of practitioners and scholars, to enable an effective and engaging training programme.

\section{Publications}

Beyond the International and Comparative Law Quarterly, BIICL publishes many of its major research projects, some of which are available free of charge, and other papers on contemporary legal issues. It also publishes a regular Newsletter.

\section{The Bingham Centre for the Rule of Law}

The Bingham Centre was launched in 2010. It is named after The Rt Hon Lord Bingham of Cornhill KG who promoted the maintenance and development of the rule of law. The Centre is devoted to the study and promotion of the rule of law worldwide, defining and implementing the rule of law as a universal and practical concept that upholds respect for human dignity and enhances economic development and political stability. 
BECOME A BIICL MEMBER

\section{TODAY}

Membership of BIICL is open to all and provides an opportunity to participate in a diverse community of practitioners, scholars and others with an interest in international and comparative law, and the rule of law.

Members are kept informed of BIICL's latest research and developments, and are able to engage in debate and discussion through our programme of topical events, seminars and conferences. Our membership includes judges, solicitors and barristers, government officials, regulators, international civil servants, academics, students, and many non-lawyers.

Various individual and organisation membership packages are available. Members receive a substantial discount on relevant events and BIICL publications, plus access to our renowned journal, the International and Comparative Law Quarterly.

To find out more about individual and organisation membership, please visit www.biicl.org/membership.

To find out more about Forum Membership, please visit www.biicl.org/forums. 


\section{INTERNATIONAL \& COMPARATIVE}

LAW

QUARTERLY

\section{VOLUME 69}

\section{PART 4}

OCTOBER 2020

When founded in 1952, the International and Comparative Law Quarterly was the only journal which offered the reader coverage of comparative law as well as public and private international law as well as European Union law. Since then it has maintained its pre-eminence amongst journals of its kind and it continues to offer practitioners and academics wide topical coverage without compromising rigorous editorial standards.

Membership of the British Institute of International and Comparative Law brings with it a subscription to the International and Comparative Law Quarterly, or it is available as a personal annual subscription from the distributor Cambridge University Press. More details are available at: biicl.org/subscriptions

Find out how to submit your paper: journals.cambridge.org/iclq/ifc

Register for ICLQ email alerts: journals.cambridge.org/iclq/alerts

Follow the ICLQ on Twitter: @iclq_jnl

Cambridge Core

For further information about this journal please go to the journal web site at: cambridge.org/ICLQ

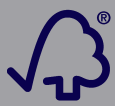

FSC www.fsc.org 